\title{
THE \&FFECT OF FISCAL POLICY ON THE SIZE OF THE INFORMAL SECTOR IN NIGERIA
}

\author{
Offiong H Solomon* \\ London Metropolitan University \\ o.solomon@londonmet.ac.uk
}

July 2011

\begin{abstract}
This paper adapts a dynamic real business cycle model to examine the effect of fiscal policy on the relative size of the informal sector in Nigeria. The motivation for this paper is to provide an economic intuition on how fiscal policy has contributed to the growth of the informal sector. The results of the model show the presence of an inverted U-shaped relationship between the tax rate and the size of the informal sector. It also predicts that for a given tax rate below a threshold of $30 \%$, public capital stock contributes to an increase in the size of the informal sector and vice versa. The theoretical predictions of the model are supported empirically using data from Nigeria between 1980 and 2000. The model finally shows that there is a proportional relationship between the agent's welfare and the size of the informal sector.
\end{abstract}

Keywords

Informal sector, business cycles, general equilibrium, tax, public goods

* Dr Offiong Helen Solomon is a senior lecturer in the Economics Department of the Business School at London Metropolitan University, London, United Kingdom. 


\section{INTRODUCTION}

This paper examines the impact of fiscal policy on the size of the informal sector in Nigeria. The informal sector has been characterised by many definitions and descriptions (see Gerxhani, 1999). According to Ekpo and Umoh (undated), the informal sector can be defined as "economic activities in all sectors of the economy that are operated outside the purview of government regulation". The informal sector in Nigeria has been described as the most dynamic in Africa. It has been noted for its entrepreneurship, dynamism and flexibility. It has emerged to play a significant role in the Nigerian economy as an alternative channel for the provision of unregulated goods and a source of employment. The informal sector is thought to absorb about $65 \%$ of the economically active population. This estimate seems to have been supported by Sethuraman (1984) and the ILO (1988). According to these authors, the informal sector has expanded from $50 \%$ of the urban labour force in the late 70 s to $65 \%$ by the late 80 s. On the other hand, in terms of gross domestic product (GDP), the size of the informal sector has variously been estimated to be 43\% (Adamu, 1996) and 37.39\% (Salisu, 2001).

Tax increases the distortion between income and post-tax income after production. As a result, there is an incentive for entrepreneurs to shift factors of production such as capital and labour from the formal sector to the informal sector to avoid tax. The informal sector is characterised by having low barriers to entry and so this attracts particularly micro-enterprises that cannot afford the taxes and other administrative fees imposed by government. This results in a high incidence of tax evasion and a significant loss of tax revenue for public investment. Furthermore, a survey on the effect of tax on the Informal Sector by Gerxhani (1999) showed that an increase in the tax rate leads to an increase in the size of the informal sector. Some key factors that have contributed to the growth of the informal sector have been excessive regulation, bureaucracy and high taxes. For instance, a 2010 report on "Doing Business in Nigeria" showed that an entrepreneur can expect to go through eight procedures over 31 days for which total cost is equivalent to $76.7 \%$ of gross national income (GNI) per capita. Consequently, the motivation is to analyse the effect of fiscal policy on the size of the informal sector because of the implications for economic growth. A second motivation for this paper is to study the welfare implications of a large informal sector owing to higher tax rates.

However, the government has also contributed to the growth of the informal sector in Nigeria in other ways. During the oil boom era of 1971 to 1977, Nigeria was transformed from a poor agrarian economy into a rich, oil-dominated one. The unexpected increase in public revenues drove the federal government to invest heavily in huge public projects (e.g. housing and public utilities), which were mainly concentrated in the urban areas. This resulted in rural-urban migration as many people came into the urban cities in search of job opportunities in administration, construction, commerce and services. As a result, the cities expanded beyond their capacity to absorb job-seekers. Those who could not find work became absorbed into the informal sector. A second factor contributing to the huge growth of the informal sector was the adoption of the Structural Adjustment Programme (SAP) from 1986 through to 1993. One of its objectives was to reduce the level of government control of economic resources and to promote private sector participation by encouraging the operation of market forces. The dependence on oil revenue prior to the SAP created a Dutch disease problem. A majority of local enterprises were unable to compete with imports. The contraction of the private sector at the small and medium enterprise level led to the loss of jobs. The loss of jobs was also mirrored in the public sector following the massive retrenchment of workers by government in order to reduce its spending. The informal sector expanded as it absorbed the unemployed from the formal sector. 
Arimah (2001) showed in an empirical study the presence of strong linkages between the formal sector and the informal sector. For instance, the informal sector is heavily dependent on the formal sector for the supply of raw materials, equipment, expertise and credit.

Due to the complex nature of the informal sector, it is difficult to access the broad impact of government policy on the size of the informal sector in Nigeria. As a result, it is important to develop economic models that help provide some economic intuition linking fiscal policy to the size of the informal sector. For example, the SAP may have expanded opportunities in the informal sector, but because of its dependence on the formal sector it was more vulnerable to business cycles than the formal sector. Meagher and Yunusa (1996) point out that during the period of the SAP, the contraction in formal sector enterprises contributed to a sharper contraction in the informal sector because of this dependence.

The paper is organised as follows: section 2 reviews the literature with respect to the effect of fiscal policy on the size of the informal sector. It also considers the application of Real Business Cycle Models (RBC) in the modelling of the informal sector. This is followed by a brief account of the history of the informal sector in Nigeria. Section 3 adapts an RBC model by McGrattan et al. (1997) to examine the effect of fiscal policy on the relative size of the informal sector. Section 4 calibrates the models parameters in order to carry out policy experiments. Section 5 tests the predictions of the model empirically using data on Nigeria from 1980 to 2000. Section 6 is the conclusion.

\section{LITERATURE REVIEW}

The general literature supports the view that an increase in the tax rate increases the size of the informal sector. Clotfelter (1983), Friedland et al. (1978) and Baldry (1987) have argued that the main causes of tax evasion are very high taxes and low audit probabilities. The consequence is the opening of various loopholes by which taxes can be avoided. For example, Schneider and Neck (1993) show that for Austria, decreasing the complexity of the tax system can increase the size of informal sector by reducing tax exemptions. According to Spicer (1986), a taxpayer will evade taxes if the expected reward exceeds the expected costs (risk of detection, fines and punishment) of evading tax. This idea has been supported empirically through the work of Johnson et al. (1998), who showed that a combination of high tax, high regulatory burden, the weak rule of law and a high incidence of corruption have contributed significantly to the increase in the size of the informal sector in some countries in Latin America. The direct link between the tax rate and the size of the informal sector has also been supported by Ihrig and Moe (2000) using cross-sectional data drawn from 32 industrialised and developing countries. Their estimates showed that a one percent increase in the marginal corporate tax rate contributes to an increase in the size of the informal sector by $0.49 \%$.

The interest of this paper in the application of RBC models to the informal sector originates from the work of Hansen (1985), Benhabib et al. (1991) and McGrattan et al. (1997), who introduced home or non-market production into a standard RBC model. These models showed that including non-market production in RBC models enables them to perform better than standard RBC models in capturing the observed data in the U.S. economy.

McGrattan et al. (1997) developed their own variation of a model with non-market production to examine the impact of fiscal policy (tax and government expenditure) on production in the market and non-market sector respectively. Their results showed that the model with home 
production is as good and in some cases better in capturing real business cycles than standard RBC models. They showed that fiscal policy in a model with non-market production produces different results to the standard RBC model. Parente, Rogerson and Wright (2000) showed that $\mathrm{RBC}$ models have also been able to account for differences in international income levels across countries.

In terms of the application of dynamic RBC models to the study of the informal sector, Roca et al. (2001) use an RBC model to show that the informal sector accounts for the differences in registered aggregate fluctuations. They focus on labour participation rates as a reason for differences in fluctuations in output. They show that the negative relationship between participation rates and registered output is due to the existence of the informal sector. Their results also showed that the informal sector accounts for about $44.3 \%$ of the differences in aggregate fluctuations. Furthermore, they used their model to generate implied sizes of the informal sector for Europe and the USA and find that the estimates are similar to those observed in the empirical literature. Ihrig and Moe (2004) analyse the impact of tax and enforcement policies on the size of the informal sector in Sri-Lanka. They find that a small increase in the tax rate causes a large increase in the relative size of the informal sector. Finally, Ferreira-Teriyaki (2008) showed that during recessions, countries that have large informal sectors tend to experience greater fluctuations in output, investment and consumption.

\subsection{The informal sector in Nigeria}

The informal sector has been given many definitions and descriptions (Gerxhani, 1999). Some of the descriptions used to characterise the informal sector include hidden, household, parallel, second, shadow and subterranean. The informal sector has also been defined according to a variety of criteria. Harding and Jenkins (1989) classify criteria according to political, economic and social criteria respectively. In this paper, I define the informal sector according to political criteria, which define the informal sector as one that produces goods and services by avoiding government regulation - e.g. avoiding taxes. However, the informal sector is also characterised by its relation to income or size of activity such as gross domestic product. This definition of the informal sector is based on the economic criteria and is useful when considering how to measure the informal sector. In this paper, the informal sector is measured in relation to gross domestic product. In general there are two main approaches to measuring the informal sector: the direct approach via conducting surveys, and the indirect approach via the estimation of the informal sector using macro models. These approaches are discussed in detail in OECD (2002) and Schneider and Klingmair (2004).

The growth of the informal sector parallels the development of the urban sector in Nigeria. The development of urban cities in Nigeria dates to prior to British colonial rule. British colonial rule contributed to the development of some of the urban cities away from their origins as centres of traditional, political and religious authority (such as Zaria, Benin, Sokoto, Arochukwu \& Ile-Ife). Other cities evolved as centres of internal and international trade (Kano, Lagos \& Calabar), while some developed as centres of defence and related purposes (Ibadan \& Abeokuta). Accordingly, the informal sector developed according to the traditional nature of the cities. Such traditional activities include agriculture, traditional crafts and small-scale industries within the formal sector. As a result, the informal sector was part of the traditional setup of these communities and not considered a separate sector.

Currently, the informal sector is engaged in a wide range of economic activities. Economic activities in the informal sector have expanded into the productive, service and financial sectors 
of the Nigerian economy. Some of these include agriculture, mining, the small-scale production of goods and services, the retail trade, transport, restaurants, repair services, financial intermediation, and household and other personal services Adamu (1996).

In Nigeria, production in the informal sector is characterised as having freedom of entry and exit, small operations, low levels of skills and low wages. Each of these characteristics shall be described in turn. Entrance into the informal sector is easy. According to Fajana (2008), entry into the informal sector has increased in recent times. New entrants are often individuals who have recently acquired new skills and have obtained a little capital from friends or family. In comparison to the size of firms in the formal sector, firms in the informal sector are smaller in magnitude. The informal sector is largely heterogeneous in nature and fragmented. The majority of operators in the informal sector can be found in retail trading, repairing, venturing, tailoring, hairdressing and acting as agents. The capacity of the informal sector to grow and expand is often limited by low capital inputs as low levels of skills among its workforce. Studies by the ILO indicate that the informal sector uses only a small fraction of capital to create jobs in the sector (Daza, 2005). The sector is unable to provide high quality goods and services, but is able to access capital through linkages with enterprises in the formal sector. Arimah (2001) conducted a survey of 1,991 enterprises spanning seven industries (agricultural services, fabrication, repairs, personal services, processing, technical services and trading and related services) across six major urban cities in Nigeria. Arimah (2001) identified two types of linkages, namely backward linkages and forward linkages. Backward linkages refer to the supply of raw materials, equipment, finance and consumer goods from the formal sector to the informal sector. Forward linkages refer to the supply of goods and services from the informal sector to the formal sector. The results showed that the relationship between informal and formal enterprises occurs mainly through backward linkages. Secondly, the lack of forward linkages has deprived the informal sector of being able to access the skills, resources and markets needed for development. He further showed that those informal sector enterprises that were able to maintain a profit margin employed a large number of employees (greater than 10), whose employees had at least primary education and whose employers had previous job experience in the public sector, and were most likely to benefit from forward linkages with the formal sector.

Meagher and Yunusa (1996) explored the relationship between the formal and informal sector respectively to examine the effect of the SAP. Their analysis was based on a survey of the informal sector in Zaria, a town in northern Nigeria. During the SAP, the exchange rate became devalued by $149.1 \%$. This contributed to a decline in real wages, leading to a large loss of jobs in both the private and public sectors. This built up pressures within the labour market to absorb the unemployed from the formal sector. As a result, real wages declined within the informal sector to such a level that it was barely sufficient for survival let alone capital accumulation. As conditions deteriorated in the formal sector, the informal sector became further entrenched in a low productivity trap. In addition, they report that the formal sector exploited the advantages available in the informal sector as a channel for marketing goods produced to the low-income consumer market. Consequently, this contracted markets for operators in the informal sector.

\section{MODELLING THE INFORMAL SECTOR}

The model consists of a representative agent, the government and two sectors - namely the formal and informal sectors. The agent only produces and consumes goods from the formal and informal sectors respectively. There are no firms in this model. The supply of labour is assumed 
to be fixed. The agent is endowed with capital stock which he invests in both sectors. In the formal sector, output is taxed by government. The tax rate is assumed to be exogenous. The government uses an exogenous amount of tax revenue to accumulate public capital stock for investment. Public capital stock is defined in terms of engineering construction component of public administration, capital stock, primary transportation systems such as subways and highways, mass transit, water supply, and wastewater treatment facilities (Harchaoui \& Tarkhani, 2003). Public capital is an externality to the agent. The agent does not anticipate how tax revenues are transferred into public capital. He does not act strategically regarding the government. In this model, it is assumed that the formal sector derives greater positive externalities from public capital stock than the informal sector. This is because the informal sector is less capital-intensive, faces barriers to production and seeks to avoid detection from government. The informal sector is characterised by four features: First, output in the informal sector is not taxed, because the government does not observe the informal sector. Secondly, all output produced in the informal sector is consumed. Thirdly, there are barriers to production in the informal sector because it lacks access to technology. Finally, output in the informal sector cannot be used for capital accumulation.

The agent chooses the next period's capital stock in each sector to maximise the expected discounted value of utility subject to his budget constraint and the evolution of capital stock in the formal sector.

\subsection{Agent-Investor}

Equations (1) and (2) describe the agent's preferences. $E_{0}$ is the expectation operator conditional on information available to the agent at time $0 . \beta$ is the discount rate. $C_{t}$ is the aggregate of consumption in the formal sector $\left(c_{1 t}\right)$ and informal sector $\left(c_{2 t}\right)$. $U$ is assumed to be continuously differentiable, concave and increasing in $c_{1 t}$ and $c_{2 t}$.

$$
E_{0} \sum_{t=0}^{\infty} \beta^{t} U\left(C_{t}\right)
$$

Where $0<\beta<1, c_{1 t} \geq 0$ and $c_{2 t} \geq 0$

$$
C_{t}=\log \left[c_{1 t}+c_{2 t}\right]
$$

\subsubsection{Production in the formal sector}

Equation (3) is the production function in the formal sector. $A_{t}$ is an aggregate shock, $k_{1 t}$ is capital stock in the formal sector and $X_{t}$ is public capital stock. Labour supply is assumed to be fixed and is normalised to one. Some proportion of output is paid as tax to the government. This tax is a direct tax on production in the formal sector. In the calibration of the model, data on corporate tax is used as a measure of direct tax to capture the role of tax burden in the private sector.

$$
y_{1 t}=(1-\tau) A_{t} k_{1 t}^{\alpha} X_{t}^{\psi}
$$

$$
0<\alpha<1 ; 0<\psi<1 ; k_{1 t} \geq 0 ; \alpha+\psi<1
$$

\subsubsection{Production in the informal sector}

Equation (4) is the production function in the informal sector. Goods produced in the informal sector are assumed to be also consumed in this sector. Labour supply is also assumed to be fixed 
and normalised to one. $y_{2 t}$ is output in the informal sector, $A_{t}$ is an aggregate shock, which also affects production in the informal sector and $k_{2 t}$ is capital stock in the informal sector. No capital accumulation occurs in the informal sector because the sector depends on the formal sector for the supply of capital through investment. The informal sector has limited access to resources such as technology and capital because it operates outside the realm of government regulation. These "barriers to production" are captured by the parameter $\phi$. The informal sector is characterised by a lower level of productivity relative to the formal sector. Therefore, the shares of physical and public capital stocks respectively relative to output are assumed to be lower relative to the formal sector.

$$
y_{2 t}=\frac{A_{t} k_{2 t}^{\lambda} X_{t}^{v}}{\phi}=c_{2 t}
$$

$0<\lambda<1 ; 0<v<1 ; \lambda+v<1$

\subsubsection{Capital stock}

The agent is endowed with capital stock and can choose to allocate this capital to produce output in either the formal sector or informal sector, as shown by equation (5). In this equation, $k_{t}$ is total capital stock, $k_{1 t}$ is the supply of capital stock to the formal sector and $k_{2 t}$ is the supply of capital stock in the informal sector.

$$
k_{t}=k_{1 t}+k_{2 t}
$$

Capital stock is perfectly mobile across sectors. Capital accumulation in the informal sector is driven by investment in the formal sector. Equation (6) shows the accumulation of capital stock in the formal and informal sector respectively.

$$
k_{t+1}=(1-\delta) k_{t}+i_{t}
$$

where $\delta \varepsilon(0,1)$ is the depreciation rate of capital stock and it is new investment in capital stock.

\subsubsection{Government}

Equation (7) shows that public investment $(\tilde{g})$ is financed from taxes collected from the formal sector. Equation (8) shows that an exogenous proportion of tax revenue is spent on public investment, while the remainder is wasted. In this model, public capital stock $\left(X_{t}\right)$ is viewed as an externality by the representative agent. $\eta \tilde{g}$ represents the proportion of public investment that is not wasted and $\eta \tilde{g}$ is the proportion of tax revenue used for public investment.

$$
\begin{aligned}
& \tilde{g}=\tau A k_{1 t}^{\alpha} X_{t}^{\psi} \\
& \eta \tilde{g}+(1-\eta) \tilde{g}=\tilde{g}
\end{aligned}
$$

where $0<\eta<1$

\subsubsection{Evolution of public capital stock}

Equation (9) shows the evolution of public capital stock. The stock of public capital in the next period is produced from the sum of public investment and the fraction of non-depreciated public capital stock.

$$
\begin{aligned}
& X_{t+1}=\left(1-\delta_{x}\right) X_{t}+\eta \tilde{g} \\
& X_{t+1}=\left(1-\delta_{x}\right) X_{t}+\eta \tau A k_{1 t}^{\alpha} X_{t}^{\psi}
\end{aligned}
$$


where $0<\delta x<1$

\subsubsection{The budget constraint}

The budget constraint in equation (10) describes the resources available to the agent. Since the agent obtains income and consumes goods from both the formal sector and informal sector, it must be the case that:

$$
y_{1 t}+y_{2 t}=c_{1 t}+c_{2 t}+i_{t}
$$

In the informal sector, since $y_{2 t}=c_{2 t}(\mathbf{1 0})$ becomes

$$
y_{1 t}=c_{1 t}+i_{t}
$$

Substituting $k_{1 t}+1$ and $k_{2 t}+1$ for it in (6) into the budget constraint in (11) yields equation (12). The left-hand side shows the agent's net output/income from the formal sector. The righthand side shows that the agent's income is used for consumption and to accumulate capital stock for investment in the formal and informal sectors respectively.

$$
y_{1 t}=(1-\tau) A_{t} k_{1 t}^{\alpha}=c_{1 t}+\left[k_{1 t+1}-(1-\delta) k_{1 t}\right]+\left[k_{2 t+1}-(1-\delta) k_{2 t}\right]
$$

\subsection{Competitive equilibrium}

Equation (13) is a Bellman equation and is the value function that solves the agent's competitive equilibrium. The agent's objective is to choose the level of $c_{1 t}$ and $c_{2 t}$ to maximise utility. The model is solved according to the dynamic programming approach developed by Richard Bellman (1957), where consumption in the formal and informal sectors respectively $\left(c_{1 t}\right.$ and $c_{2 t}$ ) is solved according to the next period's capital stock in the formal and informal sector - i.e. $k_{1 t}$ and $k_{2 t}$. This is because investment links consumption today with consumption in the next period. An increase in investment in capital stock causes a reduction in consumption today, but generates higher consumption in the next period.

$V\left(A_{t}, k_{1 t}, k_{2 t}\right)=$

$\max _{k_{1 t+1}, k_{2 t+1}}\left[(1-\tau) A_{t} k_{1 t}^{\alpha} X_{t}^{\psi}+(1-\delta) k_{t}-k_{t+1}+\frac{A_{t} k_{2 t} X_{t}^{v}}{\phi}\right]+\beta E_{t} V\left(A_{t+1}, k_{1 t+1}, k_{2 t+1}\right)$

The First Order Conditions (FOCs) in equations (14) and (15) describe how the agent will choose the next period's capital stock in the formal sector and informal sector.

FOC wrt $k_{1 t+1}$

$$
U^{\prime} c_{t}(-1)+\beta U^{\prime} c_{t+1}\left(\alpha(1-\tau) A_{t+1} k_{1 t+1}^{\alpha-1} X_{t+1}^{\psi}+(1-\delta)\right)=0
$$

FOC wrt $k_{2 t+1}$

$$
U^{\prime} c_{t}(-1)+\beta U^{\prime} c_{t+1}\left(\frac{\lambda A_{t+1} k_{2 t+1}^{\lambda-1} X_{t+1}^{v}}{\phi}+(1-\delta)\right)=0
$$

The FOCs in (14) and (15) show that agent chooses $k_{1 t+1}$ and $k_{1 t+1}$ respectively such that marginal utility of reducing consumption at time $t$ equals the expected marginal utility benefit from increasing consumption discounted by $\beta$ in the next period. The difference is that in (14), the increase in utility is the result of capital accumulation created by investment in the formal sector and public capital produced by government. In (15), the increase in utility comes from 
capital accumulation resulting from the investment of capital and public capital stock respectively in the informal sector by the formal sector.

In the steady-state, the after-tax marginal productivity of capital stock in the formal sector equals the marginal product of capital stock in the informal sector. This is shown in equation (16) :

$$
(1-\tau) \alpha A k_{1}^{\alpha-1} X^{\psi}=\lambda A k_{2}^{\lambda-1} X^{v}
$$

\subsubsection{Steady-state solutions}

Equations (17) through (20) are the steady-state solutions to capital stock in the formal and informal sector respectively as well as public capital stock.

$$
\begin{aligned}
& k_{1}^{S S}=\left[\left(\frac{\frac{1}{\beta}-(1-\delta)}{\alpha(1-\tau) A}\right)^{\frac{-\psi-1}{\alpha+\psi-1}}\left(\frac{\eta \tau A}{\partial_{x}}\right)^{\frac{-\psi}{\alpha+\psi-1}}\right] \\
& X^{S S}=\left[\left(\frac{\frac{1}{\beta}-(1-\delta)}{\alpha(1-\tau) A}\right)^{\frac{-1}{\alpha+\psi-1}}\left(\frac{\eta \tau A}{\partial_{x}}\right)^{-\frac{(\alpha+\psi+\alpha \psi-1}{(\psi-1)(\alpha+\psi-1}}\right] \\
& k_{2}^{S S}=\left[\left(\frac{\frac{1}{\beta}-(1-\delta) \phi}{\alpha(1-\tau) A}\right)\left(\left(\frac{\frac{1}{\beta}-(1-\delta)}{\alpha(1-\tau) A}\right)^{\frac{-1}{\alpha+\psi-1}}\left(\frac{\eta \tau A}{\delta_{x}}\right)^{\frac{-\left(\alpha-\psi a^{2}-\psi^{2} \alpha\right)}{(1-\psi)}}\right)^{\frac{1}{v}}\right]^{\frac{1}{(\lambda-1)}}
\end{aligned}
$$

In this paper, the relative size of the informal sector $(I)$ shall be defined as the ratio of steadystate output in the informal sector $\left(y_{2}^{s S}\right)$ to steady-state output in the formal sector $y_{1}^{s S}$.

\section{POLICY EXPERIMENTS}

In this section, the model is calibrated to examine the effects of taxes, public capital stock and an oil price shock on $I$. $I$ is defined as the ratio of steady-state output in the informal sector to formal sector respectively - i.e. $I=\frac{y_{2}^{s s}}{y_{1}^{s s}}$. Table $\mathbf{1}$ in Appendix A describes the parameters that are calibrated and the sources of each parameter value. The sources come from other related works cited in the literature as well as statistics obtained locally from the Federal Office of Statistics (FOS), Central Bank of Nigeria, Chartered Institute for Taxation in Nigeria (CITN) and the International Monetary Fund (IMF).

The parameters are calibrated to achieve a baseline $I$ of $57.9 \%$ of GNP. This figure is based on Schneider and Klingmair (2004), who estimated growth of $I$ in Nigeria from 1999 to 2000. $\alpha, \beta$ and $\delta$ are calibrated according to the literature to 0.26 (Mabanwonku, 1978), 0.85 (Male, 2009) and 0.08 (Ihrig \& Moe, 2004). The share of capital in the informal sector, $\lambda$, is set to a subjective rate of 0.05 , as the informal sector is assumed to be significantly less capital-intensive (Ihrig \& Moe, 2000). The tax rate is set to 0.30 based on the current corporate tax rate in Nigeria. $\eta$, 
which captures the proportion of tax revenue not wasted, is set to 0.3 to reflect the fact that in Nigeria, a significant proportion of tax revenue has been wasted on ambitious public projects with little economic return.

The degree of barriers to production $(\Phi)$ and shares of public capital stock in the formal sector $(\varphi)$ and informal sector $(v)$ are difficult to calibrate, as there are no direct measures for Nigeria. $\Phi$ is set to a high value of 0.99 to reflect the high degree of barriers to production faced by the informal sector. The shares of public capital for the formal and informal sector are set to 0.08 and 0.0285 respectively in order to achieve the baseline of $57.9 \%$ of GNP. Finally, the mean value of the oil price shock is set to 1 .

\subsection{The effect of tax on the size of the informal sector}

This section examines the effect of tax rates on capital stock in the formal sector $\left(k_{1}^{s S}\right)$, public capital stock $\left(X^{S S}\right)$, output in the formal sector $\left(y_{1}^{S S}\right)$ and the relative size of the informal sector $(I)$. The relative size of the informal sector is defined as the ratio of steady-state output in the informal sector $\left(y_{2}^{S S}\right)$ to steady-state output in the formal sector $\left(y_{1}^{S S}\right)$. The aim is to develop a mechanism that links changes in the tax rate to the size of the informal sector.

Table 2 in Appendix A shows the deviation in the steady-state levels of $k_{1}^{s S}, X^{s s}, y_{1}^{s s}$ and $I$ from their calibrated levels as the tax rate increases from $10 \%$ through $70 \%$. Initially, an increase in the tax rate causes a decrease in the marginal returns to capital stock and output in the formal sector. An increase in the tax rate also generates higher tax revenue for the government. This leads to an increase in the level of public investment accumulated for the production of public capital stock. Consequently public capital stock $\left(X^{s S}\right)$ increases. As long as the tax rate is less than the elasticity of public capital stock i.e. $(\tau<\varphi)$, the government produces more public capital stock. $X^{s S}$ is an externality in the production function of both the formal and informal sectors respectively. This means that an increase in $X^{s s}$ increases steady-state output in both the formal and informal sector respectively. The informal sector gains lower positive externalities from public capital stock so output in the informal sector increases by a relatively smaller magnitude. However, as $X^{s s}$ increases, the agent invests higher levels of capital stock for production in the informal sector relative to the formal sector in order to avoid tax. Therefore, the relative size of the informal sector increases.

At sufficiently higher tax rates (as $\tau$ approaches unity), there is even a further decrease in the marginal returns to capital stock and output in the formal sector. This is because a larger fraction of output in the formal sector is transferred towards the production of public capital stock by the government. Table 2 shows that an increase in the tax rate increases steady-state public capital stock. The informal sector does not pay tax but depends on the formal sector for investment of physical capital. As a result of the high tax rates, the agent has less capital stock to allocate to investment for production in the informal sector. Consequently, steady-state output in the informal sector decreases faster than steady-state output in the formal sector. Therefore the relative size of the informal sector decreases. Figure $\mathbf{1}$ in Appendix B shows the relative size of the informal sector as the tax rate increases from $0 \%$ to $100 \%$. Initially an increase in the tax rate increases $I$, but beyond the threshold tax rate of $30 \% I$ decreases. As a result of the mechanism described above, the relative size of the informal sector is characterised by an inverted U-shaped curve. 


\subsection{The effect of public capital stock on the size of the informal sector}

This section examines the effect of an increase in public capital stock on the relative size of the informal sector in the steady-state. As steady-state public capital stock is an endogenous function, eta $(\eta)$ is used as a proxy for public capital stock. This is because $(\eta)$ is the proportion of tax revenue that is not wasted, and it is this revenue that government uses to invest in public capital.

For a given tax rate, it is expected that as $(\eta)$ increases, steady-state output in the formal and informal sectors increase respectively. This is because public capital stock generates positive externalities in both sectors. Consequently, the relative size of the informal sector increases $(I)$ as $(\eta)$ increases. However, the steady-state output in the informal sector increases by a relatively lower magnitude, since it operates on a smaller scale to avoid government detection.

\subsection{Welfare issues}

In this section, the effect of an increase in tax on the agent's steady-state utility $\left(U^{S S}\right)$ is analysed. The aim is to examine if having a large informal sector that is dependent on the formal sector improves the agent's welfare. Equation (20) shows that steady-state utility is the sum of steady-state consumption in the formal and informal sectors respectively.

$$
U^{s s}=c_{1}^{s s}+c_{2}^{s s}
$$

Table 3 in Appendix A shows the effect of an increase in tax on $U^{S S}$ as the tax rate increases from $10 \%$ through $70 \%$. An increase in the tax rate reduces steady-state utility. This means that in an economy with a large informal sector, the agent's welfare decreases as the tax rate decreases. An increase in the tax rate reduces steady-state consumption in the formal sector. This is because the marginal returns to steady-state output in the formal sector decline as the tax rate increases. This increases the incentive for the agent to shift consumption from the formal sector into the informal sector. The agent does not consider it inferior to consume goods from the informal sector because goods in both sectors are perfect substitutes. Consequently the agent has less income to allocate to investment for production in the informal sector. This means that as the tax rate becomes higher, output in the informal sector declines at a faster rate than in the informal sector. Therefore steady-state consumption in the informal sector also decreases. The result implies a direct relationship between welfare and the size of the informal sector.

\section{AN EMPIRICAL ANALYSIS OF THE \&FFECT OF TAX RATE ON THE RELATIVE SIZE OF THE INFORMAL SECTOR IN NIGERIA}

In this section, we test the model's predictions with respect to the relationship between the tax rate, public capital stock and the relative size of the informal sector in Nigeria. The objective is to examine if the theoretical predictions of the model can be supported by empirical data. The theoretical model predicts the presence of an inverted $U$-shaped relationship between the tax rate and the relative size of the informal sector. Therefore, a quadratic function is assumed because this is the simplest function capable of generating an inverted U-shaped curve. Equation (21) specifies the quadratic function used to estimate the relationship between the tax rate and the relative size of the informal sector. $I_{t}$ refers to the relative size of the informal sector, $\tau_{t}$ is the tax rate, $X_{t}$ is public capital stock and $\varepsilon_{t}$ is the error term. 


$$
I_{t}=a_{0}+a_{1} \tau_{t}+a_{2} \tau_{t}^{2}+a_{3} X_{t}+\varepsilon_{t}
$$

In order to measure the tax rate, the data used is the corporate tax rate taken from the Chartered Institute of Taxation of Nigeria (CITN). In the empirical model, a proxy is used to measure public capital stock. This is Total Public Investment in Administrative, Economic and Social/Community services as a percentage of GDP respectively. This is shown in Table 4 in Appendix C. To measure the informal sector, the Multiple Indicator Multiple Cause (MIMIC) Model is used to obtain time series estimates of the size of the informal sector as a proportion of GDP and GNP from 1970 to 2000. (The time series estimates for size of the informal sector as a percentage of GDP were produced from the author's thesis "A Macroeconomic Study of the Impact of Government Policy on the Informal Sector in Nigeria". Details of the estimation are available from the author.) Measuring the size of the informal sector is difficult because the informal sector is unobserved. As a result, a number of macroeconomic models have been developed to estimate the size of the informal sector. Some of the popular macroeconomic models include the currency demand method and the physical input (electrical) consumption method. The MIMIC model is a structural equation model that uses both multiple causes and multiple indicators to estimate a variable that cannot be measured directly. The estimation generates an ordinal index, which is then converted into cardinal estimates of the size of the informal sector relative to a macroeconomic indicator such as GDP. The MIMIC model has been criticised with respect to the reliability of the estimates produced. However, it is the author's opinion that the MIMIC model is more suitable for Nigeria than the other two methods described above for the following reasons: Nigeria has been mainly a cash-driven economy for the last thirty years, so using the currency demand model would overestimate the size of the informal sector, as both sectors overwhelmingly use cash for transactions. Secondly, electricity supply in Nigeria has dwindled considerably owing to poor infrastructure. This has caused severe power outages, causing a lot of firms to rely on generators for electricity supply. Therefore using the physical electricity consumption method would underestimate the size of the informal sector. However, it is acknowledged that any method used to estimate the informal sector and the estimates that are generated have to be used and interpreted with caution. Table $\mathbf{5}$ in Appendix C presents the estimates of the size of the informal sector in Nigeria between 1970 to 2000. The sample size for the estimation is between 1980 to 2000 owing to the availability of data for public investment as a percentage of GDP.

\subsection{Results}

Equation (22) shows the results of the regression. The numbers in parenthesis are t-ratios. The results of the regression are shown in Table $\mathbf{6}$ in Appendix C. The results of the diagnostic test show that the null hypothesis of no serial correlation and no heteroskedasticity cannot be rejected using the Breusch-Goffrey and Breusch-Pagan-Godfrey tests respectively. Furthermore, the null hypothesis of an incorrect functional form for the empirical model in (21) is rejected using the Ramsey Reset Test. (The results of these tests are available upon request from the author.) The table shows that $\tau_{t}$ has a significant positive effect, $\tau_{t}^{2}$ has a significant negative effect and $X_{t}$ has a significant negative effect respectively on the relative size of the informal sector in Nigeria.

The coefficients of $\tau_{t}$ and $\tau_{t}^{2}$ show that an increase in the tax rate increases the size of the informal sector, but beyond a threshold tax rate, the size of the informal sector decreases. The coefficients are significant at the $5 \%$ level. The results also show that an increase in public capital stock decreases the relative size of the informal sector. The result is significant at the 
$5 \%$ significance level. The results of the policy experiment in section 4.1 suggested that as tax increases, an increase in public capital stock increases $I$. However, as the tax rate increases beyond $30 \%$, an increase in public capital stock decreases the relative size of the informal sector. The turning point for the tax rate in the empirical model is calculated to be approximately $37 \%$. This figure is larger than the threshold tax rate of $30 \%$ predicted by the theoretical model. Therefore, based on the policy experiments carried out in section 4 , at the tax rate of $37 \%$, it should be expected that an increase in public capital should cause a decrease in the informal sector. This is because beyond the threshold of $30 \%$, a larger proportion of the agent output goes towards the production of public capital. As a result, the agent in the formal sector has less capital stock to invest in production in the informal sector. Therefore the results of the empirical model support the theoretical model's predictions concerning the effect of tax and public capital stock on /in Nigeria.

$$
\begin{array}{r}
\widehat{I_{t}}=-0.1 .166+9.56 \tau_{t}-12.95 \tau_{t}^{2}-0.52 X_{t} \\
(-1.907) \quad(2.93) \quad(-2.98) \quad(-2.16)
\end{array}
$$

\section{CONCLUSION}

This paper set out to use a dynamic RBC model to model the effect of fiscal policy on the relative size of the informal sector in Nigeria. The model was adapted from McGrattan et al. (1997), who examined the effect of fiscal policy on an economy with home production. The model was calibrated to examine the effect of tax rates and public capital on the relative size of the informal sector. The model also considered the effect of an increase in tax on welfare.

The results of the theoretical model showed the presence of an inverted $\mathrm{U}$-shaped relationship between the tax rate and the relative size of the informal sector in Nigeria. The key component of the model is the relationship between tax rate and public capital stock. Initially an increase in tax rate generates tax revenues, which the government uses to invest in public capital stock. The increase in the tax rate decreases production in the formal sector. As a result, the agent chooses to shift capital away towards production in the informal sector in order to avoid tax. However, at sufficiently high tax rates, a larger fraction of output in the formal sector is transferred towards the production of public capital stock. This significantly reduces the amount of income left for consumption and investment in the next period. Since the informal sector depends on the formal sector for the supply of capital, output in the informal sector also decreases faster relative to output in the formal sector, and this reduces the size of the informal sector. Therefore, at sufficiently high tax rates, an increase in public capital stock reduces the size of the informal sector.

The model's theoretical predictions were tested empirically using data on corporate tax rate, public investment and estimates of the informal sector using the Multiple Indicator Multiple Cause (MIMIC) model. The results of the empirical model confirm the predictions of the theoretical model. Furthermore, a large informal sector that is dependent on the formal sector for investment decreases the agent's welfare. Through these results, the paper has contributed to the general literature by developing an economic model that provides economic intuition on the link between fiscal policy and informal sector in Nigeria.

The link between fiscal policy and informal sector in Nigeria showed that an adverse tax system contributes to a large informal sector. However, a large informal sector that is highly dependent on the formal sector is not likely to cushion the adverse effects of fiscal policy on growth. This 
means that policy should be geared towards adopting an optimal tax regime that maximises production in the formal sector so as to discourage the incentive to become informal. The results of the empirical model suggest a corporate tax rate of $37 \%$. This is because having a large informal sector dependent on the formal sector for resources is a cost rather than a benefit to society. Secondly, the informal sector tends to be largely excluded from the benefits of public capital because of its hidden status. Therefore, policy should be focused towards reducing the barriers to production in the informal sector so as to make it easier for enterprises in the informal sector to become formal. This would enable such enterprises to gain greater access to public capital, thereby increasing production. Finally, the model shows a proportional relationship between welfare and the relative size of the informal sector as the tax rate increases. This means that the informal sector can aid the formal sector to cushion the effects of adverse fiscal policy. However, this is possible only if enterprises classed as informal can have greater access to credit, training and investment.

\section{LIST OF REFERENCES}

ABA Section of Antitrust Law. (2008). Issues in Competition Law and Policy, Volume I. Chicago: ABA Book Publishing.

Adamu S.0. (1996). National Accounting in a Developing Country: The Case of Nigeria. Ibadan: SAAL Publications.

Arimah, B.C. (2001). Nature and Determinants of the Linkages between Informal and Formal Sector Enterprises in Nigeria. African Development Review, 13(1), pp. 114-131.

Baldry, J.C. (1987). Income Tax Evasion and the Tax Schedule: Some Experimental Results. Public Finance, 42, pp. 357-383.

Bellman, R. (1957). Dynamic Programming. Princeton: University Press.

Benhabib, J.R. \& Wright, R. (1991). Homework in Macroeconomics: Household Production and Macroeconomic Fluctuations. The Journal of Political Economy, 99(6), pp. 1166-1187.

Clotfelter, C.T. (1983). Tax Evasion and Tax Rates: An Analysis of Individual Return. Review of Economics and Statistics, 65(3), pp. 363-373.

Daza, J.L. (2005). Informal Economy, Undeclared Work and Labour Administration, Paper No.9, International Labour Organisation. Geneva: International Labour Organisation.

Ekpo \& Umoh(undated) The Informal Sector in Nigeria [On-line] Available:

http://www.onlinenigeria.com/links/economyAdv.asp?blurb=495. (Accessed November, 2008).

Fajana, S. (2008). The Nigerian Informal Economy: Investigating Decent Work and Pay, and National Development through Unionisation. Employee Relations, 30(4), pp. 372-390.

Ferreira, T.(2008). The Informal Economy and Business Cycles. Journal of Applied Economics, 11(1), pp. $91-117$

Friedland, N., Maital, S. \& Rutenberg, A. (1978). A Simulation Study of Income Tax Evasion. Journal of Public Economics, 10, pp. 107-116.

Gerxhani, K. (1999). Informal Sector in Developed and less Developed Countries: A Literature Survey. Tinbergen Institute Discussion Papers 99-083/2, Tinbergen Institute. 
Harding, P. \& Jenkins, R. (1989). The Myth of the Hidden Economy: Towards a New Understanding in the United States and Abroad. Philadelphia: Open University Press.

Hansen, G.D.(1985). Indivisible Labor and the Business Cycle. Journal of Monetary Economics, 16, pp. 309-327.

Harchaoui Tarek, M. \& Tarkhani F. (2003). Public Capital Stock and its contribution to the productive performance of the Canadian Business Sector. Economic Analysis (EA) research paper series, Catalogue No. 11F0027M/E, No. 017, Microeconomic Analysis Division, Statistics Canada.

IBRD, World Bank (2009). Doing Business 2010 in Nigeria. [On-line] Available: www.doingbusiness.org/Documents/CountryProfiles/NGA.pdf. (Accessed 25 March 2010).

Ihrig, J. \& Moe, K.S. (2000). The Influence of Government Policies on Informal Labour: Implications for Long-Run Growth. DEECONOMIST, 148(3), pp. 331-343.

Ihrig, J. \& Moe, K.S. (2004). Lurking in the Shadows: the Informal Sector and government policy. Journal of Development Economics, 73, pp 541-547.

IL0/JASPA(1988). African Employment Report. Addis Ababa.

Johnson, S., Kaufmann, D. \& Zoido-Lobaton, P. (1998). Corruption, Public Finances and the unofficial economy. Policy Research Working Paper No.2169, August 1999.The World Bank.

Mabawonku, A.F. (1978). Incomes and factor productivity in Western Nigeria Small Scale Industry. Developing Economies, 16(3), pp 269-282.

Male, R. (2009). Business Cycle Persistence in Developing Countries: Can a DSGE Model with

Production Chains and Sticky Prices, Reproduce the Stylised Factor Rates, 11 November 2009, Queen

Mary University of London. [On-line] Available: https://editorialexpress.com/cgi-

bin/conference/download.cgi?db_name=res_phd_2010\&paper_id=160. (Accessed April 2010)

McGrattan, E.R., Rogerson, R. \& Wright, R. (1997). An Equilibrium Model of the Business Cycle with Household Production and Fiscal Policy. International Economic Review, 38, pp. 267-290.

Meagher, K. \& Yunusa, M-B. (1996). Passing the Buck, Structural Adjustment and the Nigerian Urban Informal Sector. United Nations Research Institute for Social Development (UNRID), DP 75. [0n-line] Available: http://www.unirsd.org/unrisd/website/documents/(httpPublications)/oc598c026c83F2Dc80256-B6700506-c167. (Accessed November 2008)

$0 \varepsilon C D$ (2002). Measuring the Non-Observed Economy - A Handbook. 0ECD Publications Service.

Roca, J.C.C., Moreno, C.D. \& Sánchez, J.E.G. (2001). Underground economy and aggregate fluctuations. Spanish Economic Review, 3(1), pp.41-53.

Salisu, M. (2001). Incentive Structure, Civil Service Efficiency and the Hidden Economy in Nigeria. Discussion Paper No.2001/86. UNU/WIDER.

Schneider, F.R. \& Kligmair, R. (2004). Shadow Economies around the World: What do we Know? CESIFO Working Paper No. 1167.

Schneider, F. \& Neck, R. (1993). The Development of the Shadow Economy under Changing Tax Systems and Structures. Finanzarchiv N.F., 50(3), pp.344-369.

Sethuraman, S.V. (1981). The Urban Informal Sector in Developing Countries: Employment, Poverty and Environment. Geneva: International Labour Office.

Spicer, M. W. (1986). Civilization at a Discount: The Problem of Tax Evasion. National Tax Journal, 39, pp. 13-20. 


\section{APPENDIX A}

TABLE 1: Calibration of model's parameters

\begin{tabular}{clll}
\hline Parameters & \multicolumn{1}{c}{ Descriptions } & Value & \multicolumn{1}{c}{ Source } \\
\hline$A$ & Capital share in the Formal Sector & 0.2600 & Mabawonku (1978) \\
$B$ & Discount Factor & 0.8500 & Male (2009) \\
$\delta$ & Depreciation Rate & 0.0800 & Ihrig and Moe (2004) \\
$\lambda$ & Capital share in the Informal Sector & 0.0500 & set to baseline \\
$\tau$ & Output Tax & 0.3000 & CITN \\
$\Phi$ & Production Barriers & 0.9000 & \\
$A$ & Oil Price Shock & 1.0000 & Mean Value of Oil Price \\
& Share of Public Capital Stock in the Formal Sector & 0.0800 & set to baseline \\
$\eta$ & Proportion of Tax Revenue not wasted & 0.3000 & CITN \\
$v$ & Share of Public Capital Stock in the Informal Sector & 0.0285 & set to baseline \\
\hline
\end{tabular}

Source: Various authors as listed in final column

TABLE 2: Effect of an increase in the tax rate on the relative size of the informal sector

\begin{tabular}{lcccc}
\hline TAX RATE $(\tau)$ & 0.10 & 0.30 & 0.50 & 0.70 \\
$\begin{array}{l}\text { CAPITAL STOCK IN THE FORMAL } \\
\text { SECTOR }\left(k_{1}^{S S}\right)\end{array}$ & 0.760 & 0.612 & 0.407 & 0.208 \\
$\begin{array}{l}\text { PUBLIC CAPITAL STOCK }\left(X^{S S}\right) \\
\text { OUTPUT IN THE FORMAL SECTOR }\end{array}$ & 0.323 & 1.505 & 4.29 & 18.257 \\
$\left(k_{1}^{S S}\right)$ & 0.766 & 0.636 & 0.444 & 0.24531 \\
$I=\left(\frac{y_{2}^{S S}}{y_{1}^{S S}}\right)$ & 0.533 & 0.579 & 0.431 & 0.220 \\
\hline
\end{tabular}

Source: Own Computations

TABLE 3: The effect of the tax rate on welfare

\begin{tabular}{lcccc}
\hline TAX RATE $(\tau)$ & 0.10 & 0.30 & 0.50 & 0.70 \\
STEADY-STATE $\left(U^{S S}\right)$ & 1.113 & 0.956 & 0.609 & 0.284 \\
\hline
\end{tabular}

Source: Own Computations 


\section{APPENDIX B}

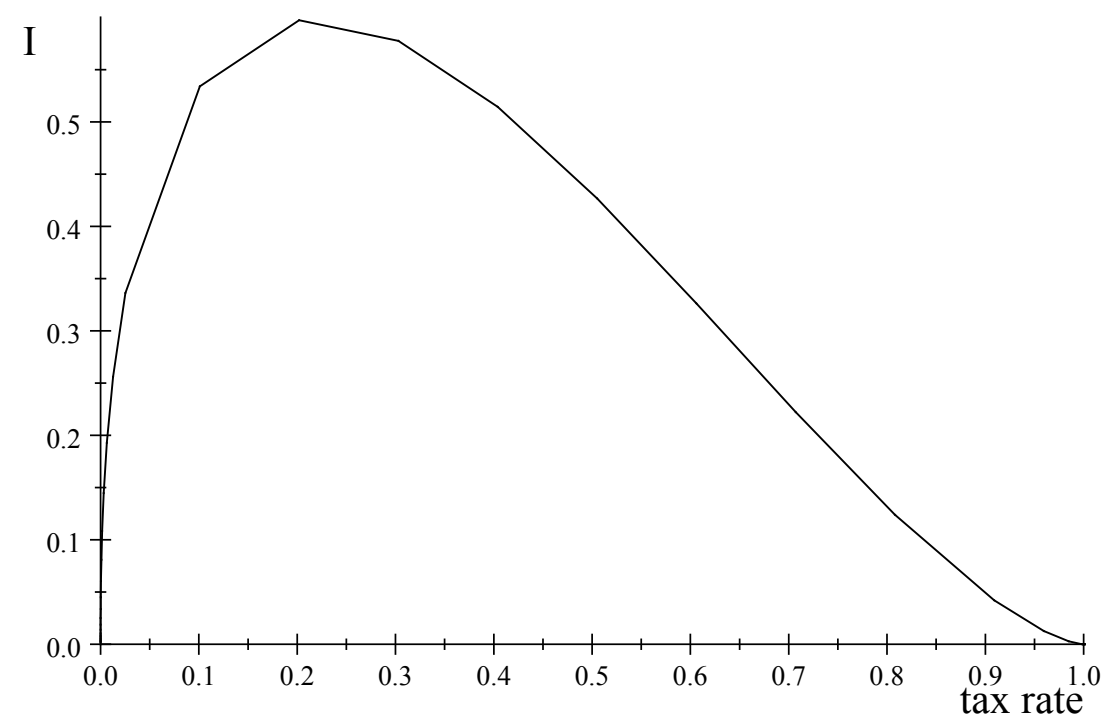

FIGURE 1: The effect of tax on the relative size of the informal sector

Source: Own computations 
THE EFFECT OF FISCAL POLICY ON THE SIZE OF THE INFORMAL SECTOR IN NIGERIA

\section{APPENDIX C}

TABLE 4: Tax rate and public investment as a percentage of GDP

\begin{tabular}{|c|c|c|}
\hline year & Tax Rate as\% of GDP & Public Investment as a\% of GDP2 \\
\hline 1980 & 0.45 & 0.199 \\
\hline 1981 & 0.45 & 0.129 \\
\hline 1982 & 0.45 & 0.123 \\
\hline 1983 & 0.45 & 0.086 \\
\hline 1984 & 0.45 & 0.065 \\
\hline 1985 & 0.45 & 0.076 \\
\hline 1986 & 0.45 & 0.117 \\
\hline 1987 & 0.40 & 0.056 \\
\hline 1988 & 0.40 & 0.057 \\
\hline 1989 & 0.40 & 0.067 \\
\hline 1990 & 0.40 & 0.087 \\
\hline 1991 & 0.40 & 0.088 \\
\hline 1992 & 0.35 & 0.073 \\
\hline 1993 & 0.35 & 0.078 \\
\hline 1994 & 0.35 & 0.078 \\
\hline 1995 & 0.35 & 0.062 \\
\hline 1996 & 0.30 & 0.056 \\
\hline 1997 & 0.30 & 0.092 \\
\hline 1998 & 0.30 & 0.108 \\
\hline 1999 & 0.30 & 0.144 \\
\hline 2000 & 0.30 & 0.049 \\
\hline
\end{tabular}

Source: $\quad{ }^{1}$ Chartered Institute of Taxation Nigeria; ${ }^{2}$ Federal Office of Statistic 
TABLE 5: Estimated size of the informal sector as a percentage of GDP

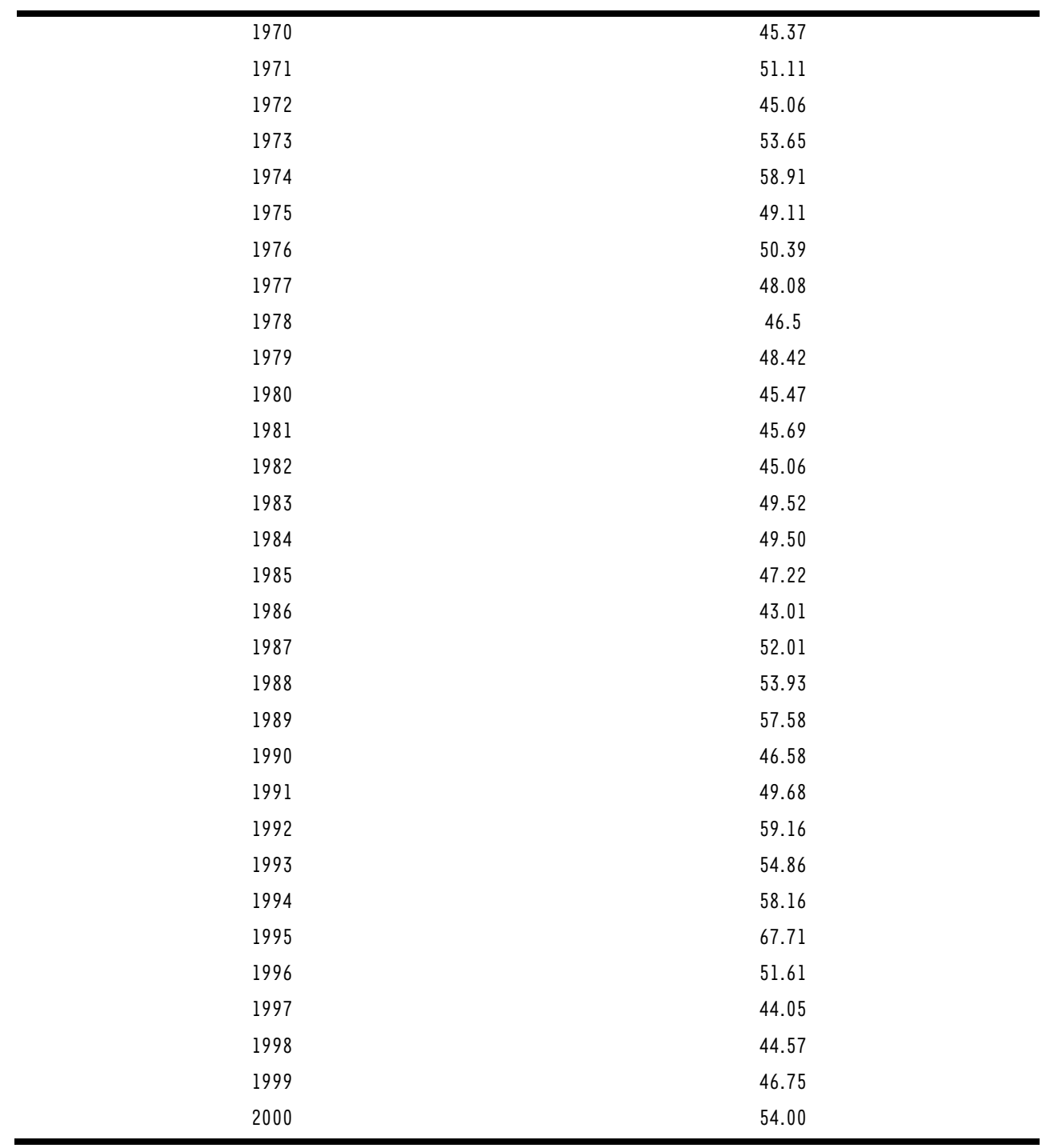

Source: Own estimates based on the Multiple Indicator Multiple Cause (MIMIC) Model 
THE EFFECT OF FISCAL POLICY ON THE SIZE OF THE INFORMAL SECTOR IN NIGERIA

TABLE 6: Results of regression model

\begin{tabular}{ccccc}
\hline \multicolumn{1}{c}{ Variable } & Coefficient & \multicolumn{1}{c}{ Std. Error } & t-Statistic & Prob. \\
\hline C & -1.163096 & 0.609803 & -1.907330 & 0.0735 \\
$\tau$ & 9.565848 & 3.260698 & 2.933681 & 0.0093 \\
$\tau$ & -12.95962 & 4.351922 & -2.977907 & 0.0084 \\
$X$ & -0.528497 & 0.315201 & -1.676700 & 0.1119 \\
R-squared & & 0.575052 & Mean dependent var & 0.507676 \\
Adjusted R-squared & & 0.500061 & S.D. dependent var & 0.062399 \\
S.E. of regression & & 0.044120 & Akaike info criterion & -3.234153 \\
Sum squared resid & & 0.033092 & Schwarz criterion & -3.035197 \\
Log likelihood & & 37.95861 & Hannan-Puinn criter. & -3.190975 \\
F-statistic & 7.668289 & Durbin-Watson stat & 1.497989 \\
Prob (F-statistic) & & 0.001872 & & \\
\hline
\end{tabular}

Source: Own estimates 